\title{
Acquiring Indonesian Pragmatic and Cultural Competencies Towards Indonesian Language Learners by Arabic Speakers at Al-Azhar University Cairo: Anthropolinguistic Perspective
}

\author{
Mamluatul Hasanah ${ }^{1},{ }^{*}$ Risna Rianti Sari ${ }^{2}$ \\ ${ }^{1,2}$ Universitas Islam Negeri Maulana Malik Ibrahim Malang, Indonesia \\ "Corresponding author. Email: risnariantisari@uin-malang.ac.id
}

\begin{abstract}
This study aims to uncover the pragmatic and cultural competencies of Indonesian Language Learners for Arabic Speakers at Al-Azhar University Cairo using an Anthropolinguistic perspective. This perspective is chosen to focus on the data of the learner's language performance which is also based on pragmatic and cultural input. The research method chosen is Spradley's ethnography of communication. The results showed that the form of pragmatic and cultural input: 1) Sourced from textbooks in the form of Communicative Expressions which are displayed in speaking materials and specific materials about Indonesian culture. 2) Authentic discourse classes joined by BIPA participants and al-Azhar students who came from Indonesia. 3) All Indonesian teachers are native speakers. 4) Initiative of BIPA students who communicate with Indonesian speakers through social media. These four inputs contribute to strengthening the pragmalinguistic, sociopragmatic, and cultural competencies of learners.
\end{abstract}

Keywords: Pragmatic Competence, Cultural Competence, Arabic Speakers, Anthropolinguistic

\section{INTRODUCTION}

The urgency of selecting research topics related to pragmatic and cultural acquisition can be seen at least from three points of view:

First, establishing international standards for language learning. The majority of continents have determined that one of the competencies that foreign language learners must have is pragmatic competence and cultural competence. Europe with its CEFR[1], America with the ACTFL, and the so-called cultural competency establishment culture relevant[2], also Australia[3] has determined that the competencies that foreign language teachers must have are linguistic competence, cultural competence, pedagogical competence, and multidisciplinary competence.

Second, based on a field study conducted by researchers on learning Arabic in Indonesia in 2014[4], it was found that the phenomenon of pragmatic failure and the absence of cultural competence possessed by Arabic learners at Maulana Malik Ibrahim State Islamic
University Malang. The main cause of failures is the lack of pragmatic input into the learning process and the absence of an immersion program held on this campus. Learning Indonesian at al-Azhar University has conditions that are almost similar to learning Arabic at UIN Maulana Malik Ibrahim Malang.

Third, paradigmatically and theoretically language acquisition in the field of language learning is divided into two aspects. To borrow a term used by Tammam Hassan[5], the two aspects referred to are al-dars and alisti'mal. Al-dars is a process that seeks to reveal language constructs from its constituent elements with an analytical perspective based on classification (tashnif) and (ta'shil). By using this paradigm orientation, the language assessment process is based on concept abstraction when the data that is not found is not the same as the predetermined language rules. This way of thinking is what leads language learners to have an established language knowledge competency. This is different from the normal process which takes language learners to something called language use. 
This paradigm looks at language data as it is used by language speakers and is not always bound by language rules. The concentration of this paradigm is more on how a language is constructed by its speakers according to their communication needs. These two paradigms have inspired many interactionist approaches in language learning. This approach makes communicative competence a goal that must be realized in language learning. And this realization requires two processes both al-dars or al isti'mal.

The fact that cultural competencies needed in every field also revealed in many researches. This cultural competencies was needed in health education because the lack of knowledge about cultural competence can be a barrier to patient management [6],[7],[8],[9]. Cultural competencies also needed in social aspect such as the important of this study among immigrant where the research results are that cultural competence can have implications for the attention of immigrants[10]. In addition to the health and social sectors, this cultural competence can also be seen in the tourism sector because it can increase insight into tourist culture which can later improve facilities for tourism[11].

Beside the cultural competencies, if we look from the historical perspective of the emergence of communicative competence in language learning, this cannot be separated from the schools of linguistic studies, namely functionalism pioneered by Halliday and Hymes[12]. One of the major contributions of this view is the attention to the relationship between language, society, and culture, which is also a concern of anthropolinguists who see language as a social tool as well as a cultural reality. In general, the fields of anthropolinguistic studies are identity, socialization, ideologies, and social space.

The pragmatic aspect of language is part of people's culture. Because the study in this study emphasizes the contribution of anthropolinguistics in the field of second language acquisition, the researchers focus more on pragmatic and cultural aspects, especially on the realization of their competencies. Pragmatic studies in language learning can be seen from two perspectives[13]; sociolinguistics or anthropolinguistics and second language acquisition. The form of pragmatic studies in an anthropolinguistic perspective emphasizes the crosscultural pragmatic form by comparing the speech act of learners with various cultural variations. As for the perspective of acquiring a second language, pragmatic studies focus more on the development of pragmatic competences by looking at the process of obtaining them, how to produce and use them.

Based on the logic above, this study will focus on how the process of acquiring pragmatic competences (from the form of input to production and use of language) of Indonesian language learners at al-Azhar University. The selection of Universitasal-Azhar as a research locus with the consideration that Indonesian language learners at this University come from various regions and even from various countries with different cultures.

\section{RESEARCH METHODS}

This research is based on functionalist linguistic, not structuralist, so that the language data obtained is not only considered language as a form, but also language is considered part of the speaker's culture. The method used in this research is communication ethnography with a qualitative Spradley approach in which the researcher lives in a community within a certain time with data sources.

The data in this study are;

a) Pragmatic and cultural input. This data is taken from textbooks, the learning process, teachers, and activities carried out by BIPA students both in class and outside the classroom.

b) The contribution of input to the competencies achieved by BIPA students is obtained from the direct interaction process carried out by researchers as well as interviews with BIPA teachers and students.

The data obtained were analyzed with an anthropolinguistic perspective with Spradley's ethnographic method of communication with conceptualization guidelines obtained from theoretical studies of pragmatic competence and cultural competence.

\section{RESULT AND DISCUSSION}

There are several things should be cleared before reveling the result of this research, such as the explanation of anthropolinguistic, pragmatics in second language acquisition studies and culture in second language acquisition studies.

\subsection{Anthropolinguistics}

In explaining the term anthropolinguistics, Duranti explains that there are three patterns; first called "Anthropological Linguistics" the focus was more on the documentation of languages [14]. Second, Anthropolinguistics focuses on theoretical studies related to the use of language. Third, Ethnolinguistics which examines the problems that are a branch of anthropology with an approach that utilizes language media. Personally, Duranti himself prefers the term anthropolinguistic because the understanding chosen is a conscious effort to redefine the study of language and culture which is considered an important part of anthropological studies. This perspective was also chosen by Hymes who understands anthropolinguistics as a study of communication and language in the context of anthropology. 
The area of anthropolinguistic studies includes three important theories; performance, indexicality, participatory. Of these three things, the focus of this research is performed.

Performance has been known as the opposite of competence. In this context, what is meant by competence is the knowledge of the language that is in mind, while performance is the reality of how language is used. And performance in the context of this research is human action with special consideration of perfect communication implementation. Three important relationships that are considered by anthropolinguistic researchers; the relationship between language and culture, the relationship between language and general culture, and the relationship between linguistics and anthropology.

When an anthropolinguistic researcher begins to study a particular language, he begins to investigate the style of language used by that society, because language is only part of the culture of that society [15]. What anthropolinguistic reviewers must avoid is to focus on the structure of language at the phonological, morphological, or syntactic level without paying attention to the culture of the language user. When the researcher enters the semantic study level, interpreting the approach is a choice that must be made.

\subsection{Pragmatics in Second Language Acquisition Studies}

Talking about pragmatics in the context of second language learning, of course, cannot be separated from communicative competence, because this competence is one of the indicators of communicative competence. Based on the opinion expressed by Jung [16] , there are five indicators of pragmatic competence in the study of second language acquisition.

\subsubsection{Ability to use appropriate speech acts.}

Based on what was stated by Rintell [17] that pragmatics is the study of speech acts, with the argument that pragmatic competence is seen when people perform speech acts, such as how people praise, how to respond when praised, how to express opinions, and so on.

\subsubsection{Interpret the meaning contextually.}

Pragmatics is the study of the relationship between language forms and the reality of their use in communication. Grice said that pragmatic ability goes back to a person's ability to understand what someone says by following the purpose of communication [18]. Carrel [19] said that one of the demands in realizing communicative competence is one's ability to make understanding conclusions during communication, while
Fraser [20] said that one of the practical competencies is one's ability to understand figurative language.

\subsubsection{Use courtesy in proper communication}

Brown and Lavinson [21] put the principles of international decency based on the logic of society. However, the implementation of these principles is still adapted to the culture of the community in using the language.

\subsubsection{Delivering the pragmatic function in the communication process.}

The success of a communication process depends a lot on one's ability to understand discourse. Blum and Kulka [22] emphasized that communicative competence requires a language sign that is agreed upon by all speakers of that language.

\subsubsection{Using the right culture in language}

The language used is the language by following the diction with the speech culture of the language being studied. A culture gives birth to a communication system, and this is reflected in speech acts.

\subsection{Culture in Second Language Acquisition Studies}

Cultural studies in the context of second language acquisition can be seen from two reinforcement approaches [23] based on knowledge and comparisons

First, strengthening is based on the knowledge base in learning cultural competence, where we see culture as the knowledge that has nothing to do with language. With this kind of thinking orientation, we see culture as a substance and reality that is conveyed to language learners

Second, the comparative approach. We see culture as something dynamic and independent. And in this context culture is seen as something very limited something with the need to solve problems in intercultural understanding

After researching for approximately 2 months, the following is a description of the findings of this study:

Cultural Pragmatic Input in the Indonesian language learning process at Al Azhar University Cairo Egypt

From the results of observations and interviews, the researcher found 4 forms of pragmatic and cultural input in the BIPA learning process at Al-Azhar.

\subsubsection{Textbooks}

(a) Communicative Expression which is the teaching material in learning to speak. Communicative expressions that are part of 
speech acts are given in stages in almost all BIPA textbooks, whether published by the Center for Strategy Development and Linguistic Diplomacy or PUSKIN.

(b) Cultural material is written specifically in textbooks. In the material section of the textbook, there is a sub-chapter of cultural notes. Also, the content of the text, both dialogue, and monologue, is a lot of content related to culture

\subsubsection{Authentic Discourses Class}

Several activities were held by BIPA course organizers collaborating between BIPA students and AlAzhar students from Indonesia.

(a) Cooking together

(b) Poetry performances

(c) Musical performances

(d) Speech

(e) Drama

Activities such as the above can be a place to gain pragmatics and intercultural competence. When Egyptian students teach how to cook Egyptian food, and vice versa Indonesian students introduce Indonesian specialties, functional and procedural texts in the cooking process also occur in the forum. Likewise, when performing collaborative art, each student understands the type of genre of the artwork they are presenting. Mastery of genre and discourse is also a pragmatic and cultural competency

\subsubsection{Native Speaker.}

All BIPA al-Azhar teachers are native speakers of Indonesian, both local BIPA teachers or teaching staff sent by PPSDK so that in the learning process in class or interactions outside the classroom there is a direct pragmatic or cultural learning process. If an error occurs the teacher immediately corrects. This form of input greatly accelerates the pragmatic acquisition process and reduces the period of developmental error experienced by learners

\subsubsection{Social media}

The results of observations and interviews conducted by researchers with BIPA students, they have a community in WA or Facebook with speakers of Indonesian and Malay in various countries. This process helps a lot in their sociopragmatic improvement

\subsection{Contribution of pragmatic and cultural input to the Al-Azhar BIPA Student Competence}

\subsubsection{Pragmalinguistic Competence}

Pragmalinguistik is one of the competencies that a person leaning a foreign language must-have. Many pragmalinguistic areas are on how the choice of diction, language structure, and vocabulary use appropriately by following the context when performing communication acts. In the process of interacting for 2 months with BIPA students in Azhar, researchers saw that their pragmalinguistic competence was quite good, especially the choice of communication expression when communicating.

\subsubsection{Sociopragmatic Competence}

Sociopragmatics is no less important than pragmalinguistic, which focuses on the use of social rules that affect speech culture such as how to praise the right way, ask questions appropriately during learning, express opinions, and so on. BIPA 6th and 7th level of students are also familiar with the small talk style that is unique to Indonesia

\subsubsection{Cultural Competence}

Many Indonesian cultures have been reflected in BIPA students, among the observers observed during their interaction with them is their culture of greeting teachers first, making tea for teachers, handing over assignments with their right hand (mostly Egyptians lefthanded), no longer sitting at the desk when studying, not making a loud voice when communicating with teachers and so on.

Pragmatic and cultural competence becomes a very interesting issue because it is an essential part of language competence. Mastering all language skills is not enough in mastering the target language, it is better if someone who wants to master the target language as a whole must complete the mastery of pragmatic and cultural competencies.

This research is in line with the Tulgar's research [24] in her article that discusses pragmatic competencies for foreign language learning. The role of pragmatic competence is to equip students with pragmatic knowledge. The importance of this competency must be socialized to foreign language learners so that they can practice it in various linguistic contexts. 


\section{CONCLUSION}

Based on the findings above, several recommendations from this study are

a) Maximizing pragmatic input and Indonesian culture in the learning process or outside of learning.

b) Making pragmatic and cultural competencies a part of the focus in learning evaluation

\section{REFERENCES}

[1] J. L. M. atall Trim, "Common European Framework of Reference for Languages: Learning, Teaching, assessment. Council of Europe. Language Policy Unit." Strasbourg: Cambridge University Press.

[2] Council of Chief State School Officers, "Interstate Teacher Assessment and Support Consortium (InTASC) Model Core Teaching Standards: A Resource for State Dialogue. Washington, DC: Author." 2011.

[3] S. Norris, "Language Teacher Proficiency or Teacher Language Proficiency: An Environmental Scan of Information realating to competencies/qualities/knowledges required to be an affective language teacher. A report preapared for the nalsas taskforce.," 1999.

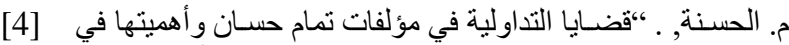

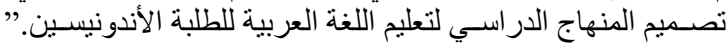

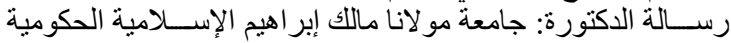

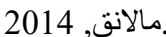

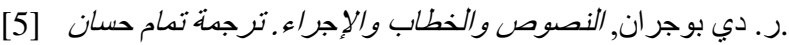
Norwood New jersey: Alex Publishing Corporation, 1998.

[6] C. Hill, C. Deville, S. Alcorn, A. Kiess, A. Viswanathan, and B. Page, "Assessing and Providing Culturally Competent Care in Radiation Oncology for Deaf Cancer Patients," Adv. Radiat. Oncol., vol. 5, no. 3, pp. 333-344, May 2020, doi: 10.1016/j.adro.2020.02.007

[7] Y. S. Üzar-Özçetin, S. Trenoweth, and S. Tee, "Migration and mental health care: Identifying the cultural competency of Turkish nursing students," Nurse Educ. Today, vol. 85, p. 104257, Feb. 2020, doi: 10.1016/j.nedt.2019.104257.

[8] H.-F. Liang, K.-M. Wu, C.-C. Hung, Y.-H. Wang, and Y.-C. Chen, "Evaluation of nursing students' perceptions of their cultural care competency: A mixed method study in Taiwan," Nurse Educ. Pract., vol. 41, p. 102639, Nov. 2019, doi: 10.1016/j.nepr.2019.102639.

[9] M. J. Mokel and L. Canty, "Educational outcomes of an online educational intervention teaching cultural competency to graduate nursing students," Nurse Educ. Pract., vol. 46, p. 102832, Jul. 2020, doi: 10.1016/j.nepr.2020.102832.
[10] B. Pokharel, J. Yelland, A. Wilson, S. Pantha, and A. Taft, "Culturally competent primary care response for women of immigrant and refugee backgrounds experiencing family violence: A systematic review protocol," Collegian, p. S132276962030113X, Oct. 2020, doi: 10.1016/j.colegn.2020.08.009.

[11] J.-H. Lin, D. X. F. Fan, S.-H. Tsaur, and Y.-R. Tsai, "Tourists' cultural competence: A cosmopolitan perspective among Asian tourists," Tour. Manag., vol. 83, p. 104207, Apr. 2021, doi: 10.1016/j.tourman.2020.104207.

[12] N. C. Ellis and D. L. Freeman, "Language Emergence: Implications for Applisd Linguistics Introduction to the special Issues," Oxf. Univ., vol. 27, 2006.

[13] J. Cenoz, "The Acquisition of Pragmatic Competence and Multilingualism in Foreign Language Context," Springer, 2007.

[14] A. Duranti, Anthropology Linguistic. Cambridge University Press, 1997.

[15] Mandelbaum, G. W. Lasker, and E. M. Albert, The Teaching of Anthropology. American Anthropological Association.

[16] J. Ji-Young, Issues in Acquisitional Pragmatics. 2004.

[17] E. M. Rintell, "Getting your speech act together: The pragmatic ability of second language learners," Working Papers on Bilingualism, vol. 17, 1979.

[18] P. Cole and J. L. Morgan, "Speech acts," N. Y. Acad. Press, vol. 3, pp. 41-58.

[19] P. L. Carrell, "Inferencing in ESL: Presuppositions and implications of factive and implicative predicates.," Language Learning, vol. 34, 1984.

[20] B. Fraser, "Perspectives on politeness," 1990.

[21] H. D. Brown, Principles of language learning and teaching, 5th ed. White Plains, NY: Pearson Longman, 2007.

[22] S. Blum-Kulka, "Discourse pragmatics," Thousand Oaks CA Sage, vol. 2, pp. 38-63, 1997.

[23] S. T. K. Ho, “Adressing Culture in EFL Classroom: The Challenge of Shitting from a Traditional to an Intercultural Stance," Electronic Journal of Foreign Language Teaching 6 (, 2009.

[24] A. Takkaç Tulgar, "The Role of Pragmatic Competence in Foreign Language Education," Turk. Online J. Engl. Lang. Teach., vol. 1, no. 1, pp. 1019, Jan. 2016, doi: 10.32959/tojelt.229304. 